\title{
The New Approach for Risk Regulation in Banks
}

\author{
Daniela Feschiyan, Radka Andasarova \\ University of National and World Economy, Sofia, Bulgaria
}

\begin{abstract}
The purpose of this report is to present the necessity of proceeding to new reforms in bank regulation and to increase the stability and risk sensitivity of the capital base under applying the Standardised Credit Risk Assessment Approach (SCRA) in banks. The dynamics in the bank regulation and supervision of credit risk assessment approaches are explored. In the paper, a thorough theoretical-methodological and historical-logical analysis was made of the evolution of the development and chronology of the global regulatory frameworks for banks-Basel 1, Basel 2, and Basel 3. The contemporary projections and challenges for the banks' management under the new regulatory and institutional changes are presented. The SCRA is a positive asset in bank capital regulation in contemporary banking. The revisions to the regulatory framework by Basel 3 are a long continuous process influenced by numerous economic, social, and political factors. The preparation of the Bulgarian banking system for a new reform of financial regulation is analyzed. The need for adoption of a new risk-based approach for capital assessment and the importance of transparency in bank financial reporting is proved.
\end{abstract}

Keywords: Basel Committee on Banking Supervision (BCBS), standardised approach (SA), credit risk, bank exposures, risk-weighted assets (RWA)

\section{Introduction}

Banks in the EU are at the verge of introducing new regulatory and institutional changes in the context of increasing the stability and risk sensitivity of the capital base under applying the Standardised Credit Risk Assessment Approach (SCRA). The Basel Committee on Banking Supervision (BCBS) held a number of discussions and empirical analyses, resulting in the conclusion that the risk-based approach that is applied to measuring capital is subject to criticism. Critical analyses and recommendations focus on its changing state and uncertainty when doing a more precise risk weighting of assets (BCBS, 2013). It proceeds from the fact that the applicable SCRA ${ }^{1}$ is based on awarded external credit ratings. Practically, there are numerous problems in the areas described below that are arising from the relations between the credit ratings agencies, banks, and supervising authorities.

(1) Mechanical confidence of banks in credit ratings. It is necessary to apply an advanced standardised

Daniela Feschiyan, Dr., professor, Department of Accountancy and Analysis, University of National and World Economy, Sofia, Bulgaria.

Radka Andasarova, Dr., chief assist, Department of Accountancy and Analysis, University of National and World Economy, Sofia, Bulgaria.

Correspondence concerning this article should be addressed to Daniela Feschiyan, Faculty of Finance and Accountancy Faculty, Department of Accountancy and Analysis, University of National and World Economy, Office 1040, "8 dekemvri" Str, Sofia 1700, Bulgaria.

1 The Standardised Credit Risk Assessment Approach (SCRA) is used by the vast majority of EU banks within or outside Basel Committee jurisdictions 
approach based on the comparability (contradistinction) of the credit ratings given by an external rating agency and the individual judgement (assessment) by the bank management for the purposes of the risk weighting of exposures.

(2) Lack of sufficient number of clients with assigned ratings in the bank's portfolio. Applying a new approach to standardised risk modeling based on fixed risk weights on specific exposure groups will improve the reliability and transparency of the risk-based approach to credit risk assessment.

Violation of the regulatory framework leads to expensive supervisory actions that could limit the functioning of the bank. Consequently, banks have an incentive to maintain higher capital positions than required (capital buffer), as insurance against breaching the minimum capital requirement for regulatory purposes (Milne \& Whalley, 2001). This theory is a reference point to the understanding of maintaining the minimum regulatory capital required by the Bank for International Settlements (BIS) through regulatory authorities.

\section{Contemporary Dimensions and Perspectives to the Revised Basel 3 Framework}

The concepts underlying in Basel 2 and subsequently in Basel 3 include three separate sections, called pillars: (1) minimum capital requirements; (2) a supervisory overview of capital adequacy; and (3) market discipline. A fundamental principle in the application of the three-pillar approach is the adoption of a "risk-based approach to institutional intervention by supervisors by creating good practice for managing and supervising the risks of banking activity" (Feschiyan, 2005, p. 36).

The financial and economic crisis since 2007 revealed that some Tier 1 instruments failed to take on the dynamics of the banks' risk profile. According to Quignon (2011), this is particularly true for privileged shares in English-speaking countries. In September 2010, The Group of Central Bank Governors and Heads of Supervision announced higher requirements for minimum capital standards in the banking sector, known as Basel 3. The aim of the changes is to increase banks' ability to face challenges arising from financial and economic stress and reducing the risk of switching from the banking system to the real economy. In other words, in the framework of the Third Basel Accord, a large number of banks must maintain more and better-quality capital than the previous regulatory frameworks-Basel 1 and Basel 2.

In December 2017, the Basel Committee on Banking Supervision published the proposed reforms to the current Basel 3 standard. The new rules (called Basel 4 by some authors) were designed to prevent taking too many risks from financial institutions. The revised standardised approach to credit risk compared to the existing standardised approach contains the following benchmarks:

\section{Applying of an Advanced Standardised Approach for Exposures to Rated Banks and Exposures to Rated Corporates With Credit Ratings}

The Committee and the professional community are aware of the need to implement the so-called "due diligence" analysis. It is emphasized that in the case of a higher risk weight in the process of individual analysis, banks must apply the higher risk weight for the respective exposure.

\section{Introducing a New Standardised Credit Risk Approach for Exposures to Unrated Banks}

The new risk assessment model provides a modern toolbox that enables supervisors to easily track risk-weighted assets without having to prove and analyse their internal risk management rules and models. To this end, banks should group their exposures into three separate sections called classes: 
1. Class A ( $\checkmark$ high ability to timely meet financial commitments, including interest and principal repayment; $\checkmark$ good capital ratios going beyond minimum regulatory requirements, including capital buffer requirements);

2. Class B ( $\checkmark$ significant credit risk as a result of unfavorable changes in business conditions or the economic environment; $\checkmark$ deviation from certain capital requirements, including capital buffer requirements)

3. Class $\mathrm{C}$ ( $\checkmark$ very high risk of insolvency and non-payment; $\checkmark$ low ability to repay financial commitments; $\checkmark$ violation of the mandatory minimum regulatory requirements set by the national supervisory authority).

Three classes of exposures are defined, and the risk-weighted value is obtained by multiplying by the corresponding risk weight, which varies between $20 \%$ and $150 \%$.

\section{Applying an Improved Standardised Credit Risk Approach for Exposures to Unrated Corporates}

For exposures to corporate, a more detailed table has been developed (see Table 1). A specific risk weight is applied to exposures to small- and medium-sized enterprises (SMEs) ${ }^{2}$. In addition, the revised standardised approach includes self-treatment of exposures to project financing, facility financing, and the financing of the supply of raw materials and commodities.

Table 1

Risk Weights for Exposures to Unrated Corporates and for Retail Exposures

\begin{tabular}{|c|c|c|}
\hline Exposure classes & Risk weight of assets under Basel 3 & $\begin{array}{l}\text { Risk weight of assets under the revised Basel } 3 \\
\text { framework }\end{array}$ \\
\hline $\begin{array}{l}\text { Specific exposures to SMEs } \\
\text { without credit rating }\end{array}$ & Unregulated & $85 \%$ \\
\hline Retail exposures $^{3}$ & $75 \%$ & $75 \%$ \\
\hline
\end{tabular}

Source: BCBS (2017) and Official Journal of the European Union (2013).

\section{Introduction of a New Standardised Credit Risk Approach for Exposures Secured by Mortgages on Immovable Property}

The calculation of the risk-weighted exposure amount is based on the new ratio proposed by the Basel Committee, which does not exist in the current framework-loan-to-valuation (LTV). The high LTV values correspond to a higher risk asset, resulting in a higher risk weight for risk exposure that will "burden" equity significantly more and vice versa. When calculating and analyzing the LTV, it is not negligible that the loans granted as a separate category of a financial asset are recognized and stated in the bank's financial statements under amortized cost (Feschiyan, Filipova-Slancheva, Andasarova, \& Daskalov, 2017).

\section{Analysis of Capital Requirements for Credit Risk in Banks in Bulgaria-Empirical Study}

In this part of the study, as a natural extension of the previous two points, an empirical analysis of the capital requirements dynamics for credit risk is made about the applicability of the risk weighting approach of the assets in the Bulgarian banking system. The survey is based on an analysis and assessment of the official data on the banking system of Bulgaria published by the BNB in the period 2014-2017 and on the published reports from banks in 2017. An important feature of the analyzed period is the introduction of the Third International Capital Standards Accord-Basel 3, reflected in the adoption of Directives 2013/36/EC ${ }^{4}$ and

\footnotetext{
${ }^{2}$ Corporate exposures to small- and medium-sized enterprises (SMEs) whose net sales revenue from the previous year is equal or does not exceed BGN 100 million.

${ }^{3}$ Including exposures to individuals and exposures to SMEs (provided that the exposure value does not exceed EUR one million).

${ }^{4}$ Directive 2013/36/EC of the European Parliament and of the Council of 26 June 2013 on the taking up and pursuit of business of credit institutions and on prudential supervision of credit institutions and investment firms OJ L 176.
} 
Regulation 575/2013/EU (Official Journal of the European Union, 2013). There is no significant change in the ratio of the main risks to which banks in Bulgaria are exposed during the reviewed period. The credit risk continues to determine the trends in the balance sheets of bank credit institutions. The analysis of the capital requirements for credit risk in banks shows static values for the period 2014-2017. The percentage share of capital requirements for its coverage is over $88 \%$ of the total capital requirements for covering all risks in the banking system (see Figure 1).

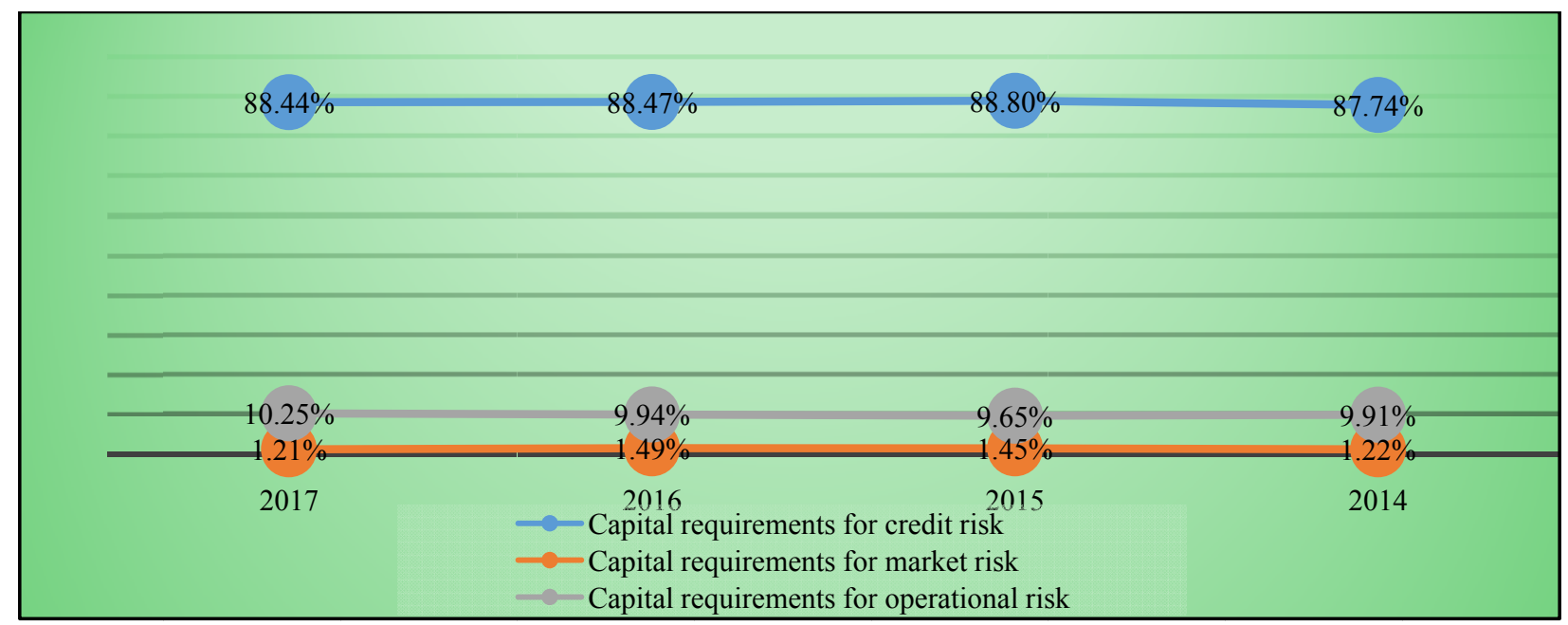

Figure 1. Capital requirements for bank risks in Bulgaria, for the period 2014-2017. Source: BNB, bank supervision: supervisory disclosure, statistical data.

The adopted changes to the bank regulation in 2013, linked to the introduction of new global capital standards (Basel 3), contribute to achieving better results, which are a prerequisite for confidence in the banking system in the country. In this respect, during the analyzed period, the share of the capital requirements for credit risk rose by $30 \%$, maintaining its high values—over $88 \%$ at an average of $58 \%$ in the period prior to the adoption of the Capital Requirements Directive of the EU and its Regulation (2007-2013) (see Figure 2).

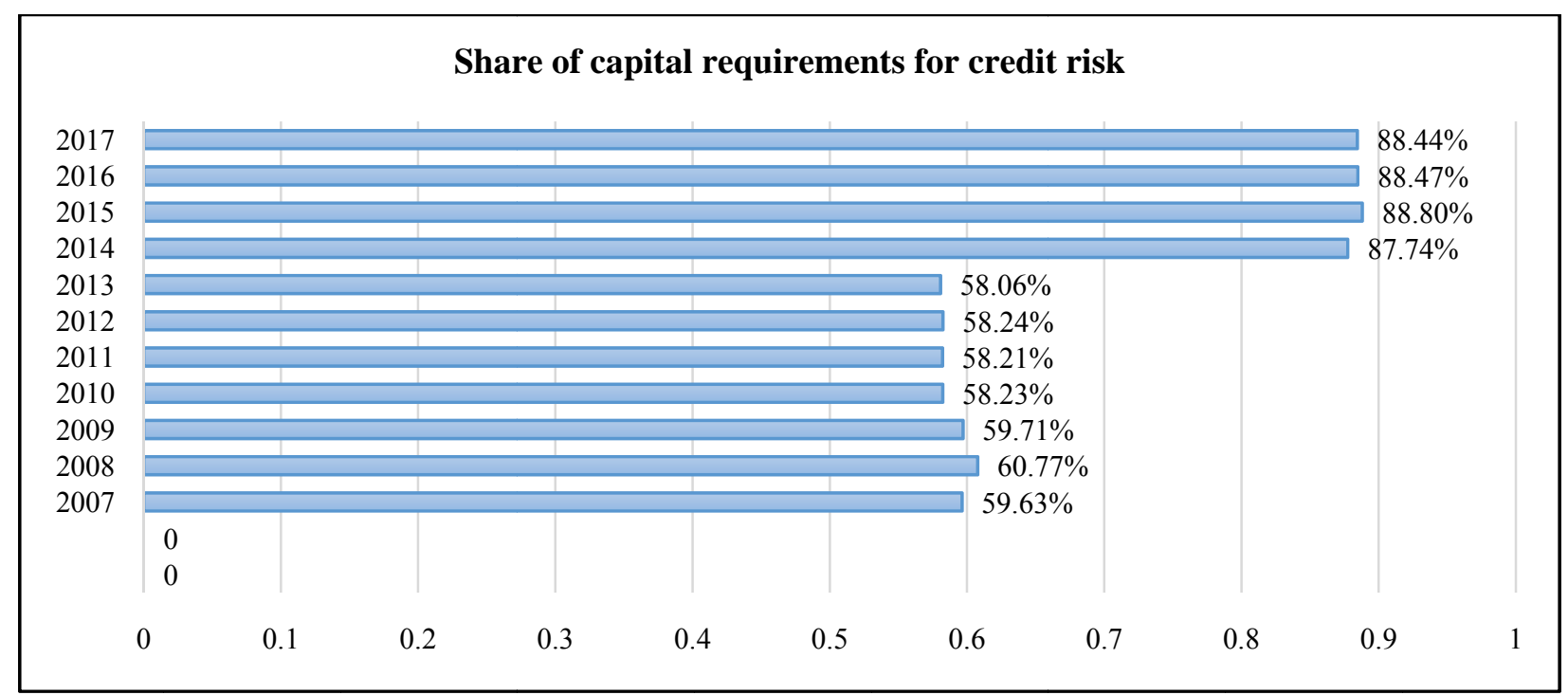

Figure 2. Dynamics in capital requirements for credit risk, 2007-2017. Source: BNB, bank supervision: supervisory disclosure, statistical data. 
Based on the officially published data on the banking system by the BNB in the period 2014-2017, a statistical survey of the approaches used for credit risk assessment and the effect of their application in the banking system in Bulgaria was made.

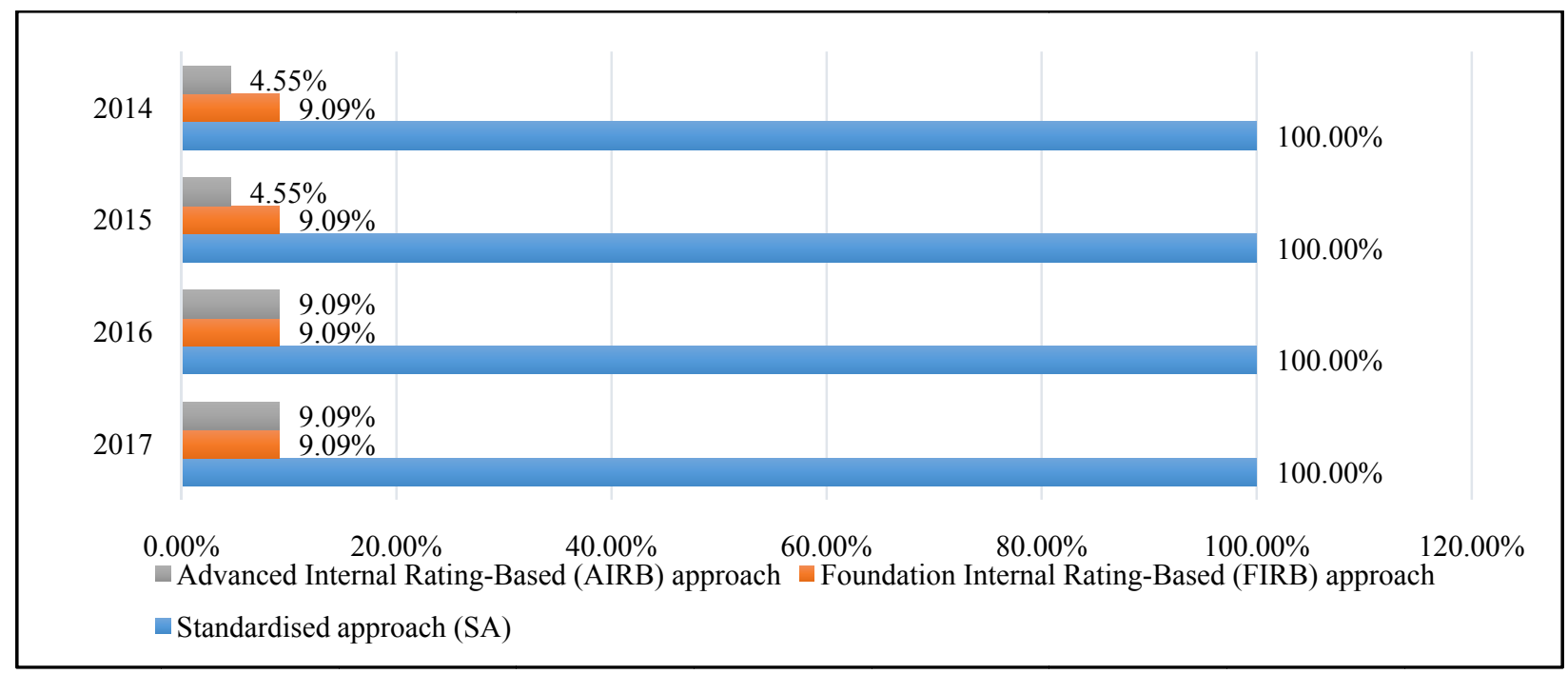

Figure 3. Normative approach to credit risk assessment for the period 2014-2017 (as a \% of the total number of credit institutions in Bulgaria).

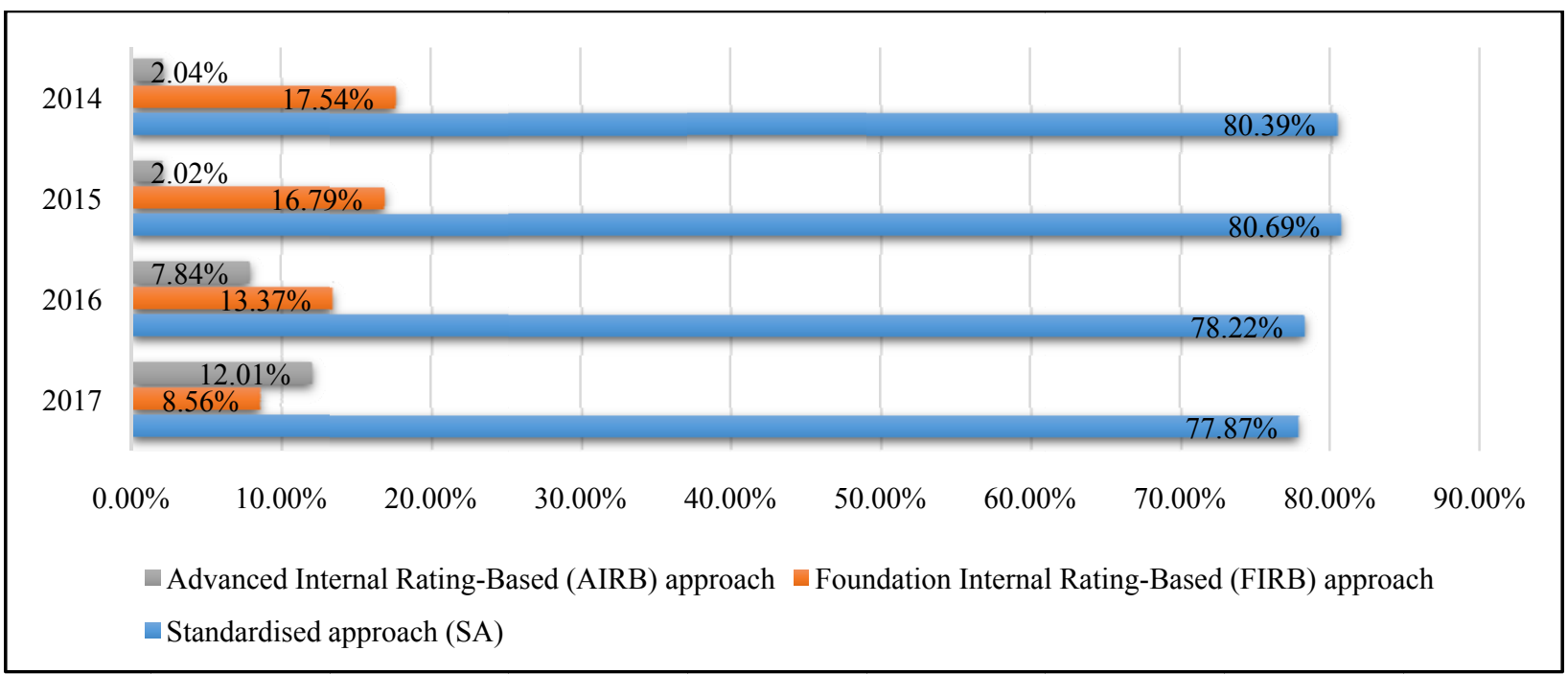

Figure 4. Normative approach to credit risk assessment for the period 2014-2017 (as a \% of the capital requirements for credit risk). Source: BNB, bank supervision: supervisory disclosure, statistical data.

Experts' expectations that at the initial application of the Basel 2 requirements, and then with the introduction of Basel 3, most banks will use the standardised approach based on assigned external credit ratings have now been confirmed. At of the end of 2017, all banks in Bulgaria applied the SCRA. Inversely, the relative share of the applicability of the internal ratings-based approach from banks in Bulgaria is about $9 \%$ or $14 \%$ of the total capital requirements for credit risk (see Figures 3 and 4).

Under Basel 3, following the Basel 2 provisions, the amount of risk weights depends on the class of assets and on the credit ratings assigned. The main classes of assets (exposures) that are subject to risk weighing are 
those to central governments; financial institutions; corporates, retail exposures; exposures secured by mortgages on immovable property, etc. For the calculation of the capital requirements for credit risk, banks determine the risk-weighted value of the exposure. The risk-weighted value of the exposure is calculated by multiplying the exposure value by the risk weight.

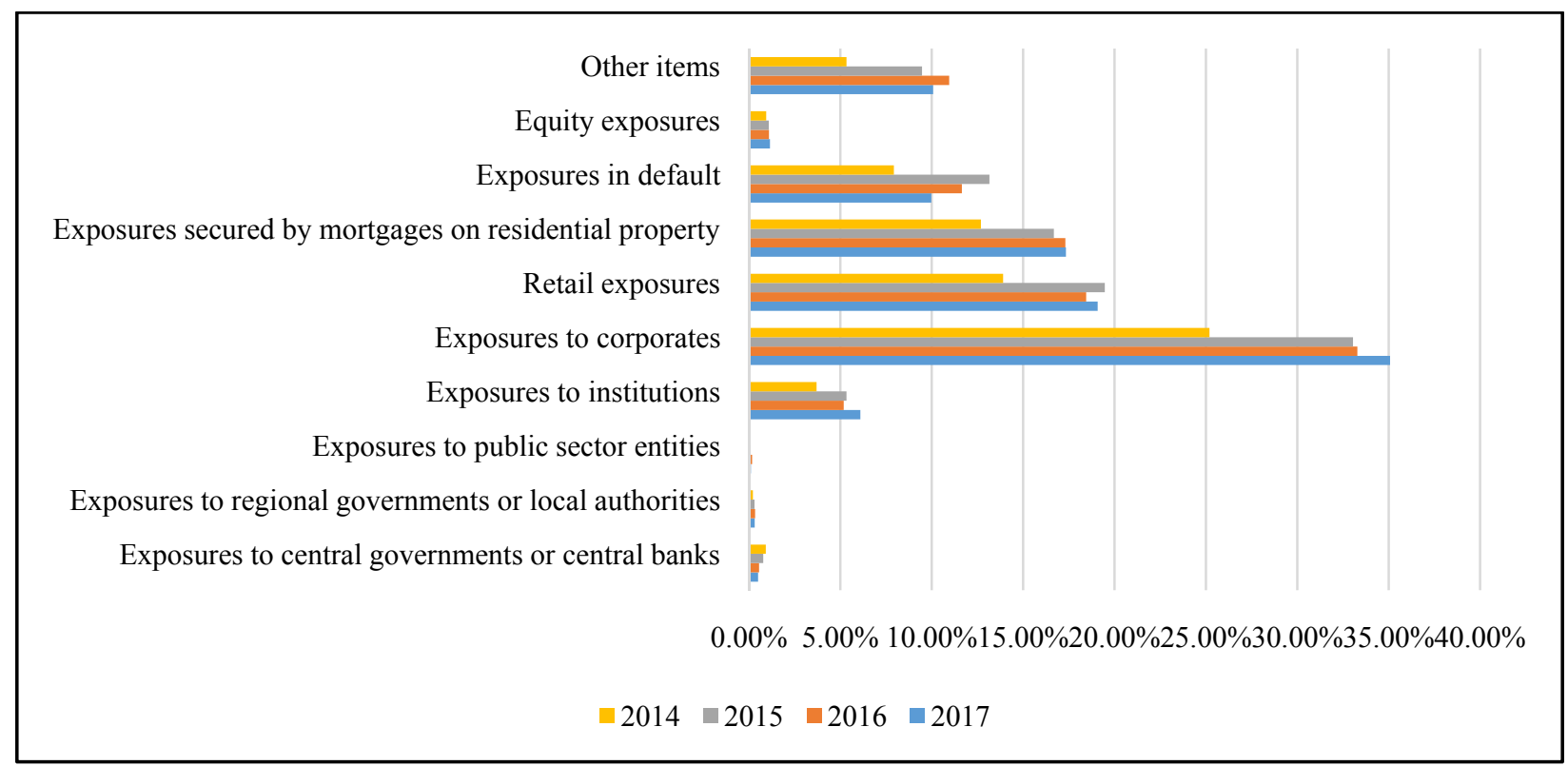

Figure 5. Dynamics of capital requirements for credit risk by exposure classes, 2014-2017(as a \% of the total amount of risk-weighted exposures under the SA). Source: BNB, bank supervision: supervisory disclosure, statistical data.

In the surveyed period, with the highest relative share in the total amount of the capital requirements for credit risk is the "Receivables from enterprises" exposures class-31\%, followed by the "Retail exposures" class with an average of $17 \%$, and the "Exposures secured by mortgages on immovable property" class with $16 \%$ share. It is not to be neglected that the proposed new supervisory rules, incl. specific rules for exposures to small- and medium-sized enterprises (SMEs) without a credit rating and stricter regulation of mortgage-backed exposures on real estate will affect the exposure classes with the greatest weight in determining the sensitivity of banks' equity to credit risk.

The methodology for determining risk weights when applying the SA is essential for the analysis - the use of assigned credit ratings by a recognized Credit Ratings Agency (CRA) or the application of standardised assessments subject to the requirements of Regulation (EU) 575/2013 for exposures without an assigned credit rating. On the basis of the officially published supervisory data of banks in Bulgaria, it is noticeable that credit institutions use credit ratings issued by recognized CRA mainly for exposures to central governments, central banks, and financial institutions, as of 31 December 2017, the largest share has the "Exposures to financial institutions" class. For other classes of exposures to corporates, retail exposures, and exposures secured by mortgages on immovable property, banks in Bulgaria apply standardised risk weights, as defined in Regulation (EU) $575 / 2013$, depending on the credit quality by classes of risk exposures.

\section{Conclusion}

It is important to note that the theoretical knowledge and study of the possible effects of the dynamics in the regulation and supervision of the credit risk assessment approaches as an important component determining 
the stability of the capital adequacy and the effective functioning of the banks is evidence of the growing role and importance of external regulation on the banking system to ensure bank investments and the efficiency of investments in bank capital.

The adopted new rules for bank regulation of credit risk management (Basel 4) will find the strongest reflection in the Bulgarian banking system in the following two directions:

(1) Change in the SA for the "Receivables from enterprises" exposure class in the part "Corporate exposures to small- and medium-sized enterprises (SMEs) without credit rating" by introducing additional criteria for their categorization and assignment of $85 \%$ risk weight. Compared to the current approach, exposures to SMEs without a credit rating that do not qualify for inclusion in the "Retail Exposures" class receive a $100 \%$ risk weight.

(2) Introducing a new standardised credit risk approach for mortgage-backed exposures on real estate based on the loan-to-valuation (LTV) indicator. Depending on the values of the indicator, banks will assign new risk weights ranging between $20 \%$ and $105 \%$. According to data from banks' supervisory reports for 2017, the highest risk weight assigned by banks in Bulgaria for the "Mortgage-backed exposures on real estate" class is $100 \%$.

\section{References}

Basel Committee on Banking Supervision (BCBS). (2013). Regulatory Consistency Assessment Programme (RCAP)—Analysis of risk-weighted assets for credit risk in the banking book. Retrieved September 10, 2018, from https://www.bis.org/bcbs/publ/d363.htm

BCBS. (2014). Consultative document-Revisions to the standardised approach for credit risk. Retrieved September 15, 2018, from https://www.bis.org/press/p141222a.htm

BCBS. (2015). Consultative document-Revisions to the standardised approach for credit risk. Retrieved September 9, 2018, from https://www.bis.org/bcbs/publ/d307.pdf

BCBS. (2016). Reflections of a Basel Committee Chairman. Retrieved August 19, 2018, from https://www.bis.org/speeches/sp161130.htm

BCBS. (2017). Basel III: Finalising post-crisis reforms. Retrieved August 23, 2018, from https://www.bis.org/bcbs/publ/d424.pdf

Feschiyan, D. (2005). Schetovodstvoto kato iztochnik na informatsia za upravlenie na kapitalovata adekvatnost na bankite I novoto Bazelsko sporazumenie za kapitala. Sofia, UI: Stopanstvo.

Feschiyan, D., Filipova-Slancheva, A., Andasarova, R., \& Daskalov, Y. (2017). Standartizirani modeli za schetovodno otrazyavane na finansovite aktivi v bankite. IDES, (3), 1-30.

Milne, A., \& Whalley, A. E. (2001). Bank capital and incentives for risk-taking. Retrieved May 10, 2018, from https://papers.ssrn.com/sol3/papers.cfm?abstract_id=30317

Official Journal of the European Union. (2013). Regulation (EU) No 575/2013 of the European Parliament and of the Council of 26 June 2013 on prudential requirements for credit institutions and investment firms and amending Regulation (EU) No 648/2012. Retrieved January 20, 2018, from https://eur-lex.europa.eu/legal-content/EN/TXT/PDF/?uri=CELEX:32013R0575\&rid=1

Quignon, L. (2011). Basel III No Achilles "Spear". BNP Paribas Corporate and Investment Banking. Retrieved from https://economic-research.bnpparibas.com/Views/DisplayPublication.aspx?type=document\&IdPdf=19035 